\title{
Antecedents and Consequences of Innovation and Business Strategy on Performance and Competitive Advantage of SMEs
}

\author{
Setyani Dwi LESTARI ${ }^{1}$, Farah Margaretha LEON ${ }^{2}$, Sri WIDYASTUTI ${ }^{3}$, Nora Andira BRABO ${ }^{4}$, \\ Aditya Halim Perdana Kusuma PUTRA ${ }^{5}$
}

Received: April 04, 2020 Revised: April 25, 2020 Accepted: May 07, 2020

\begin{abstract}
The study aims to develop concepts originating through empirical research models to build superior competitiveness and optimal performance achievement. Therefore, to bridge these goals, the study addresses several indicators/items as a novelty, namely, entrepreneurship insight factors, market orientation, knowledge-sharing, innovation, managerial capability, product strategy, process and service improvement, resources capability to improve performance and increase competitiveness by empirical model direct, mediating and indirect effect. The total sample in this study is 497 eligible SMEs that partner with go-food in Makassar City. All research samples are the owner or the person in charge of the business; the data collection period is from May to December 2019. Data are collecting using a survey with 64 construct questions, summarized in seven manifest variables. The research method uses quantitative tools, with SMART-PLS as a statistical tool. This study develops sixteen hypotheses; all of the hypotheses are supported both directly, indirectly, and mediated. The study also found that the link based on CCT, RBV, and TAM Theory is the right choice of theories, as the foundation of this study was very reliable and valid. Indeed, all of the grounded methods have implications both in theory and its main application for the business in the online marketplace.
\end{abstract}

Keywords : Innovation, Strategic Business Management, Competitive advantage, Resource-Based View, Technology Acceptance Model

JEL Classification Code: L8, L81, L84, M31.

\section{Introduction}

${ }^{1}$ First Author and Corresponding Author. Associate Professor, Magister of Management, Faculty of Economics and Business, Universitas Budi Luhur, Jakarta, Indonesia [Postal Address: JI. Ciledug Raya, South-Jakarta, Jakarta 12260, Indonesia] Email: setyani.dwilestari@budiluhur.ac.id

${ }^{2}$ Associate Professor, Faculty of Economics and Business, Universitas Pancasila, Jakarta. Indonesia. Email: widyastuti.sri@ univpancasila.ac.id

${ }^{3}$ Full Professor, Faculty of Economics and Business, Department of Management, Universitas Trisakti, Jakarta. Indonesia. Email: farahmargaretha@trisakti.ac.id

${ }^{4}$ Associate Professor, Faculty of Economics and Business, Universitas Pancasila, Jakarta. Indonesia. Email: widyastuti.sri@ univpancasila.ac.id

${ }^{5}$ Assistant Professor, Faculty of Economics and Business, Department of Management, Universitas Muslim Indonesia. Email: adityatrojhan@gmail.com

(c) Copyright: The Author(s)

This is an Open Access article distributed under the terms of the Creative Commons Attribution Non-Commercial License (http://Creativecommons.org/licenses/by-nc/4.0/) which permits unrestricted noncommercial use, distribution, and reproduction in any medium, provided the original work is properly cited.
The contribution of SMEs to the Indonesian economy is reasonably large GDP; in the 2009-2013 period, the participation of SMEs reached $57.6 \%$, with an average growth of $6.7 \%$. In 2018 the contribution of SMEs to Indonesia's GDP reached 39.66\% (Purwantini \& Anisa, 2018). In 2015, the number of SMEs was estimated to reach 60.7 million, and most of them are micro businesses (98.73\%), with their growth since 2011-2015 reaching 2.4\%. The capacity of SMEs in absorbing the workforce in 2015 continues to increase at an average of $5.9 \%$, with a total workforce of more than 132.2 million people. The development of the SME industry, including the food and beverage SME sector in Indonesia, is extensive (Ramlawati et al., 2019). In 2017, $41.69 \%$ of the total Creative Economy GDP in Indonesia was occupied by the culinary industry in the first place.

Makassar, as the eighth-largest city in Indonesia, also entered the ranks of cities in Indonesia that experienced an increase in the total of food and beverage SMEs (makassar. antaranews.com, 2010). The positive impact of that is an opportunity for the online transportation business to be able to synergize with culinary industry players in terms of 
promotion and sales. One of Indonesia's online transportation applications, 'Gojek,' with a sub-service called 'Go-food,' makes the culinary industry feel as a place of delivery orders in the online marketplace. Appendix 2 explained the development of SME Culinary as a Go Food partner in Makassar City, Indonesia. Based on the rating criteria, 4.55 score, and the average product price criteria IDR40,000100,000 .

Hudson et al. (2001) explain the measurement of SME performance based on four dimensions. First, quality, which consists of product performance, reliability in delivery, and innovation success. Secondly, time, which includes accuracy in the delivery process, shipping effectiveness, production consistency, labor effectiveness, and resource utilization in supporting the production and distribution process. Third, market share, service, and image factors. Fourth, labor conjunctions, workforce involvement, skills, work quality, and productivity. In Indonesia, the obstacle in managing HR in SMEs lies in the recruitment process, the difficulty of employers in setting rules, the challenge of employees directing employees related to the vision and mission of the business, problems in developing employee competencies, challenges in assessing performance, difficulty in determining reward and punishment methods, problems in dealing with employee demands, and challenges in retaining employees.

Competitive advantage, according to Distanont and Khongmalai (2018), is conducted efficiency for a successful business. Lorenzo et al. (2018) reveal the basic dimensions of business strategies such as resource stability, competitive strategies, and the ability to transfer technology as the main ideas. Lorenzo et al. (2018) states that competitive advantage can be achieved through four elements, namely, eliminating barriers to enter the competition, supplier strengths, buyer strengths, and accuracy in making decisions in case of competition intensity on the market. The RBV has become a subject of study that has been frequently reviewed in various studies. The pioneer of RBV (Porter, 1981), revealed the competitive advantage factor to be the main factor in winning the competition. Although Porter's RBV concept in 1981 found many critics who thought the approach could not be fully used to measure real competitive advantage without addressing cost positioning and differentiation as a fundamental part of measuring the success of the company's strategy (See Nurhilalia et al., 2019; Barney, 1991; Amit \& Schoemaker, 1993).

Objectively, this study aims to develop concepts originating through empirical research models to build superior competitiveness and optimal performance achievement. Therefore, to bridge these goals, the study addresses several indicators/items as a novelty, namely, entrepreneurship insight factors, market orientation, knowledge sharing, innovation, and managerial capability, product strategy, process and service improvement, and resources capability to improve performance and increase competitiveness.

\section{Literature Review and Hypotheses Development}

\subsection{Theoretical Background}

The dimensions of marketing channel, marketing innovation, product segmentation, and customer insight approaches are based on the Consumer Culture Theory and Technology Acceptance Model Theory, which are the right choice of theories for the foundation of this study. Ioanid et al. (2018) applies a model approach to innovation by making the CCT theory the basis of innovation. The study produces implications for implementing and developing new ideas in modern marketing, business knowledge, and integrated management governance, $R \& D$, and share of the employee as an effort to maximize innovation. Ionaid, et al. (2018) also added that in the marketing concept in the 4.0 era, the production process is not only based on the quantity and quality of products, but also inter-connections involving internal and external business parties through time optimization and cooperation (Ioanid et al., 2018). Elrehail (2018) uses the competitive advantage theory approach, and a resource-based view shows that there is a positive and significant relationship between entrepreneurship, innovation, and business strategy.

Opinions about innovation are diverse (e.g., Limaj \& Bernroider, 2019; Yi, Han, \& Cha, 2018), more emphasis is placed on innovation performance based on business capabilities in explorative and exploitative innovation. The indicators used by Limaj \& Bernroider, (2019) are the ability of organizations to meet the expectations of consumers and customers, new product innovations and TQM, using products themselves within the company's internal environment as an effort to build advocacy for consumers, and the courage to try to enter more marketing channels as e-commerce, as well as the price-oriented emphasis on quality and quantity. Rajapathirana and Hui (2018) found that innovation success factors were pursued through innovation capability, innovation type, innovation performance, market performance, and financial performance. In measuring market innovation, Rajapathirana and Hui (2018) use the fulfillment and technology-based promotion techniques to monitor sales movements. Rajapathirana \& Hui (2018) also stressed the importance of aspects of developing and increasing the value of original products through the addition of features as part of exploitative innovation, as well as the use of machines 
to replace human labor. Research by Rajapathirana and Hui (2018) shows satisfying results to ensure management effectiveness; the ability of innovation is proven to deliver business to be more productive and perform well.

Knowledge sharing is a method or step in the Knowledge Management cycle that is used to provide opportunities for members of a group or organization to share knowledge with other members. Elrehail, (2018) developed the concept of knowledge sharing with the entrepreneurship approach in which the transformational and authentic entrepreneurship as the person responsible for creating knowledge sharing in their business. Transformational entrepreneurship emphasizes the essence of an entrepreneur, namely, the ability to inspire and motivate employees, the ability to stimulate ideas and influence. Whereas authentic entrepreneurship emphasizes self-awareness, the ability to build transparently-oriented relationships to a moral perspective. Other opinions about entrepreneurship insight (e.g., Kubíčková et al., 2014) emphasize aspects of the ability of an entrepreneur to process customers, the ability to increase sales, and the ability to break through the competition. Distanont \& Khongmalai, (2018), with the Destructive Theory approach, suggest that there is a positive relationship both direct and indirect between market orientation, innovation, and competitive advantage.

Business performance that is built on integrated business strategies, innovation, entrepreneurship abilities, and knowledge-sharing capabilities, is incomplete without a market-orientation approach. Market orientation is essential for companies in line with increasing global competition and changing customer needs. Market orientation is a commitment to continue to be creative in generating superior value to customers. Distanont \& Khongmalai, (2018) state that market orientation is based on customer, supplier, and industry orientation. Customer orientation is an effort made by the industry that leads to the creation of customer-oriented innovations. Supplier orientation emphasizes the transfer of knowledge between suppliers and retail agents, which is an essential factor in the development of new products and services. Knowledge exchange and introduction of ideas and recommendations related to the selection of raw materials by suppliers that are useful for companies in creating innovation. Industry orientation, is the synergy between suppliers and industry. Kubíčková et al. (2014) state that there is a significant relationship between entrepreneurship, innovation, and performance. Ho et al. (2017) state that there is a relationship between market orientation, innovation, and business performance.

Entrepreneurship insight model with dimensions was developed by (Kubíčková et al., 2014). It refers to the ability to increase sales, the ability to compete, and the ability to present superior products. Ruiz-Ortega et al. (2017) found that entrepreneurial orientation influences innovation. (Abdolmaleki
\& Ahmadian, 2016) show the link between market innovation and competitive advantage. Alpkan, Şanal, and Ayden (2012) find links between market orientation, business performance, and innovation. (Kubíčková et al., 2014; Rega et al., 2014; Ibrahim \& Heng, 2015) find positive relationships between knowledge sharing, innovation, and business performance.

Knowledge sharing developed by (e.g., Elrehail, 2018; Rega et al., (2014) with dimensions such as SME's Commitment, Perceived Business, Employee Recognition, Marketing Channels, Product Segmentation, Marketing Innovation, Customer Insights and Decision Support by using the RBV, CCT, and TAM approaches to find a link between entrepreneurship, knowledge sharing, and innovation. Therefore, departing from prior research, the conceptual analysis developed in this study is explained as in Appendix 1 and the hypotheses developed are as follows:

H1: Market orientation has a positive and significant effect on entrepreneurship insight

$\mathrm{H}$ 2: Entrepreneurship insight has a positive and significant impact on innovation

H3: Innovation has a positive and significant impact on SME performance

H4: Market orientation has a positive and significant effect on knowledge sharing

H5: Knowledge sharing has a positive and significant impact on business strategy

H6: Business strategy has a positive and significant impact on competitive advantage

H7: Competitive advantage has a positive and significant effect on SME performance

H8: Market orientation has a positive and significant impact on business strategy by making knowledge sharing as mediating

H9: Knowledge sharing has a positive and significant impact on competitive advantage by making business strategy variables as mediating

H10: Market orientation has a positive and significant effect on competitive advantage by creating knowledge sharing and business strategy as mediating

H11: Market orientation has a positive and significant impact on innovation by making the entrepreneur insight as mediating

H12: Business strategy has a positive and significant effect on SME performance by making competitive advantage as mediating

H13: Knowledge sharing has a positive and significant impact on SME performance by making business strategy variables and competitive advantage as mediating

H14: Market orientation has a positive and significant effect on competitive advantage by creating knowledge sharing and business strategy as mediating 
H15: Entrepreneurship insight has a positive and significant impact on SME performance by making the innovation as mediating

H16: Market orientation has a positive and significant effect on SME performance by making the variable entrepreneurship insight and innovation as mediating

\section{Research Methods}

\subsection{Samples}

The total population in this study is 766 SMEs that partner with go-food in Makassar City. Determination of the sample used a purposive random sampling approach. However, from the selection of the normality and outliers of the results of the respondents' answers, there are 497 valid samples. All subjects of the sample are the owner or the person in charge of the business; the data collection period was from May to December 2019.

\subsection{Measurement and Research Design}

Measurement of variable components (See. Appendix 4) used surveys to measure respondents' perceptions. The measuring scale used is the 1-6 ordinal Likert scale (Strongly Disagree - Strong Agree). The component variables, such as Entrepreneurship Insight (X1), consist of measurement items, e.g., transactional, and Authentic Entrepreneurship refers to research by Elrehail (2018). Market orientation (X2) with items, e.g., customer orientation, suppliers, industry, refers to studies by Distanont and Khongmalai (2018); Ho et al. (2017). Knowledge sharing (X3) with items, e.g., SME commitments, business perceptions, employee work involvement, decision-making systems, refer to studies by Rega et al. (2014); Ibrahim and Heng (2015); Razak et al. (2016). Innovation (Y1) with items, e.g., marketing channels, marketing innovations, product segmentation, and customer insights, refer to studies by Limaj and Bernroider (2019); Ioanid et al. (2018); Rajapathirana and Hui (2018); Giannikas, McFarlane, and Strachan (2019); Chuang and Lin (2013); Iqbal, Huq, and Bhutta (2018); Ramlawati and Putra (2018); Murali, Pugazhendhi, and Muralidharan (2016). Business strategy (Y2) with items, e.g., managerial capabilities, product-service processes, resource capabilities, refer to research by Lorenzo et al. (2018). The measured SME performance (Z1), e.g., profitability, and assets, refers to the study by Limaj and Bernroider (2019). Competitive advantage (Z2) refers to research by Distanont and Khongmalai (2018).

The data analysis method used is Partial Least Square (PLS). The data analysis test tool uses Smartpls 3.0 software. Stages of analysis consist of testing the validity and reliability, and evaluating the outer-model with convergent validity.
The expected convergent validity criteria are $>0.7$ (Chin, 1998; Fornell \& Larcker, 1981), inner-evaluation models by reviewing the value of R Square (R2) with the criteria if the value of R2 is at about $0.5-0.67$ (meaning good), 0 0.33 (meaning moderate), and $0-0.19$ (meaning weak). Next, review the value of F-Square (f2) the assessment criteria if the value is 0.02 (meaning weak). 0.15 (meaning medium), and 0.35 (meaning large). (Chin, 1998; Hair et al., 2014). Finally, testing the hypothesis that the criteria for measuring significance and probability values $<0.05$.

\section{Results and Discussion}

\subsection{Partial Least Square Analysis}

Appendix 3 illustrates the characteristics of respondents who state that, based on sex, the majority are female; based on the age group, the majority of respondents are in the age bracket 34-41; based on marital status, the majority are married; based on education level, the majority of respondents are high school graduates.

Appendix 5 explains the goodness-of-fit model, stating that all components of the variable are declared to have met the test requirements. (e.g., Cronbach's alpha, rhoa_A, composite reliability, and AVE produce all values $>0.60$ ). As shown in Appendix 5, regarding the Entrepreneurship insight variable (X1) one item (EI2) was removed from the test due to a weak loading factor. With the transactional entrepreneurship indicator (TW), the most dominant construct is EI4 $=0.739$, and with the authentic entrepreneurship indicator (AE), the most dominant construct is $\mathrm{EI} 7=0.873$.

Regarding the Market Orientation (X2) variable, the most dominant construct with Customer Orientation indicator $(\mathrm{CO})$ is $\mathrm{MO} 2=0.874$, and the most dominant construct with Supplier Orientation (SO) is MO5 $=0.856$. With Industrial Orientation (IO), the most dominant construct is MO8 $=0.778$. In the Market Orientation variable, several constructions are removed (MO3; MO9).

As regards the Knowledge Sharing (X3) variable, the SME Commitment (SC) indicator's most dominant cost structure is KS4 $=0.874$. The most dominant construct of Employee Engagement (EG) is KS9 $=0.864$, and the most dominant item of Decision System (DSS) is KS11 $=0.890$. However, all constructs of Business Perception (PB) are removed from testing.

About the Innovation variable (Y1), the most dominant construct of Marketing Channel (MC) indicator is IN3 = 0.835; however constructs IN1 and IN2 are removed from the test. With Product Segmentation (PS), the most dominant construct is IN8 $=0.826$. With Marketing Innovation (MI), the most dominant construct is IN5 $=0.863$, and with Customer Insight (CI), the most dominant construct is IN11 $=0.894$. 
Regarding the Business Strategy (Y2) variable, the most dominant construct with Managerial Capability (MC) indicator is $\mathrm{BS} 3=0.924$. With Products, Process and Services (PPS), the most dominant construct is BS4 $=0.865$, and with Resource Capability (RC), the most dominant construct is $\mathrm{BS} 7=0.817$.

Looking at the SME Performance (Z1) variable, with Benefits indicator (PRT), the most dominant construct is SMP1 = 0.934, and with Asset (AAs), the most dominant construct is SMP5 $=0.858$. The construct SMP3 was deleted.

Regarding the Competitive Advantage (Z2) variable, with Superior Efficiency (SE), the most dominant construct is CA1 $=0.897$. With Superior Quality (SQ), the most dominant construct is CA5 $=0.831$, and with Customer Responsibility (CR), the most dominant construct is CA7 = 0.884 .

R-Square test (See. Appendix 5) illustrates that overall the variables have a reliability value above 0.67 , so it can be concluded that the overall test variable has a reliability value that is included in the first category. The average R-square value of the dependent variable is 0.870 , which, if assumed, means all independent variables have a close relationship with the dependent variable of $87 \%$.

While on the test results F2 (See Appendix 5) shows the relationship that the partial effect of variables innovation (Y1) of the SME Performance is medium (0.197 > 0:15), as well as the relationship partially between competitive advantage (Z2) of the SME Performance, is $0154>0.15$.

\subsection{Hypotheses test}

Referring to the results hypothesis testing and significance (See. Appendix 6) show that as many as sixteen hypotheses designed on the basis of the literature review show a positive and significant effect.

\subsection{Discussion}

A growing business is a business where activities put the portion of customer-orientation and customer-satisfaction as priorities and establish harmonious relationships with customers. Excellent service means consistent service from the start of promotion of the product to after sell services maintenance. Then, the success of a business is also inseparable from the role of the suppliers and the industrial orientation. Supplier orientation has its demanding side. Cooperation between suppliers is not only based on profitability, but it is also hoped that the education process and information exchange related to new products will become trends in the market. So that the synergy can create a more significant competitive advantage and a healthy business cycle, especially to overcome problems in supply chain management.
Running optimally or not the market orientation in supporting business processes, depends on the level of entrepreneurship insight of businessman. Entrepreneurship insight is a benchmark that distinguishes one businessman from another, and this insight will also determine the direction of innovation that will be developed for his products and business both in the short or long term. The character of entrepreneurship for a businessman today is increasingly complex because the pattern and level of competition have shifted a lot. Today, business is not only profit-oriented, but must also create intangible added value to all parties (employees, consumers, and society). For example, intangible added value to the internal side of the company, such as providing rewards in the form of material and non-material, intellectual skills so that they can lead well and with authority. Therefore, the ideal character for a leader is to be firm and agile.

In line with this study, the innovation factor is supported by four indicators. In essence, business activities must be supported by the ability of promotion on technologybased promotional channels to enable a product to be easily recognized by potential customers. The realization of entrepreneurship insight-based innovation requires businesses to understand every detail of the item being promoted. Therefore, consistency in maintaining quality products will increase consumer confidence about the product. Related to winning the business competition, a business person is not only required to sell products to the target, but also to be able to educate existing consumers and potential customers. Therefore, entrepreneur insight can also play a role in shaping the character of businesses in understanding market segmentation.

This is associated with innovation from the perspective of TAM and consumer culture theory, especially for companies that operate in the online marketplace. Data protection and privacy security are critical elements to consider, including quality control and accuracy in responding to customer complaints.

The pattern of innovation that will be applied certainly depends on the characteristics of a businessman and entrepreneur insight he possessed as discussed earlier, knowledge and insight about management would make it easy for an entrepreneur to be wise in taking every opportunity amid the existing risks. Knowledge management is undoubtedly not only required to be good at creating products, but also to train business people in formulating marketing strategies. Innovation is a tangible manifestation and key to the success of the sustainable business (Shmelev et al., 2018; Chamidah, Guntoro, \& Sulastri, 2020).

Market orientation is essential for the company, in the context of increasing competition and changing customer needs. Being aware of these changes, a person in business 
must always be close to his market. The positive effect between market orientation and knowledge sharing assumes that the two variables are integrated. Knowledge sharing can help companies and business people in accelerating the transfer of knowledge around business processes, problems that occur in each work unit, so that work processes become more dynamic and integrated.

In other words, business strategy through knowledge sharing can be realized as long as it fulfills several aspects such as the desire of leaders to give responsibility, the willingness of leaders and organizations to want to provide training and competency improvement, communication and feedback between leaders to employees (Akob, Arianty, \& Putra, 2020), rewards, and recognition as a result of evaluations of the performance achieved (Haerani et al., 2020). Knowledge sharing and employee involvement can be made if individuals within the scope of the organization trust and believe in the organization.

In running a business, especially a digital-based SME businesses such as those in this study, the emphasis on aspects of strategy is the thing that is required to be applied to position the industry amid competition. Analysis that has been built previously in the statistical testing stage shows that the relationship/influence is positive and significant between business strategy and competitive advantage. As stated by many previous studies, it is also justified. The critical success factor of competitiveness is supported by how the implementation of a business strategy is carried out. Digital-based SME culinary business spearheaded by Go-Food shows that the level of competition is increasingly dense and rapid. At any time, new business activities can be found as competitors emerge. In the perspective of business strategy, there are three main strategies, namely, the managerial capability of a businessman, the ability of a businessman to develop his vision and mission of an ideal business that is not only profit-oriented (size), and his ability to increase the value-added between industry, consumers and society. Therefore, accurate information, best services, and the achievement of quality per consumer expectations require business people to be able to move actively to think about it. Another managerial capability is the ability to interact proactively with customers; it is also the key to success in building quality and accurate business strategies. Furthermore, to develop a sound and ideal business strategy requires the businessman's attention to the quality of the product both in quantity and quality or in other words, the right amount and the right quality. To support the proper conditions can be pursued by maintaining the process of each product production selectively and adequately. Because in the business process, suitability between the products offered and the products given to consumers must be following the facts between the products sold and advertised so that consumer confidence can be maintained.

\section{Conclusions}

The competitive advantage of a business must have three aspects to be able to compete: 1) Superior efficiency capabilities. For example, the use of efficient budgets that are illustrated through the selection of appropriate technology to cut variable costs and business capabilities in producing products that are following market needs and close to sources of raw materials (industry). 2) The ability to maintain superior quality. For example, the ability of businesses to present quality products at competitive prices, the strength of companies to provide faster and more responsive delivery of goods, and the ability of companies to give guarantees about products marketed have excellent durability. 3) Business ability in terms of responsibility to customers. The perspective of consumer culture theory and TAM, in today's business domination in the online marketplace, makes consumer behavior and consumer culture also change along with the increasing market alternatives in the community. Therefore, the quality of service to consumers that places consumers as targets as well as business partners is something that is increasingly calculated and written in business strategies today.

In the case of SMEs with business operations using digital channels, business performance can be realized optimally if all work activities run effectively and efficiently so that they generate an optimal increase in profit and exceed the target. This also relates to the ability of a business to continue to run its activities with existing liabilities. Besides, in essence, improving business performance is to reflect aspects of employee comfort, employee satisfaction, and employee loyalty. Full support from the RBV aspect of all potential resources aims to improve the competitiveness of a business on its performance. In addition to the achievement of predetermined targets, technological support from the TAM aspect plays a role in achieving competitiveness and improving business performance, and in the end, in meeting consumers' expectations in perception and behavior can also be collected as an element of supporting competitive success.

\section{References}

Abdolmaleki, K., \& Ahmadian, S. (2016). The Relationship between Product Characteristics, Customer and Supplier Involvement and New Product Development. Procedia Economics and Finance, 36(16), 147-156. https://doi.org/10.1016/S22125671(16)30026-0

Akob, M., Arianty, R., \& Putra, A. H. P. K. (2020). The Mediating Role of Distribution Kahn's Engagement: An Empirical Evidence of Salesforce in Indonesia. Journal of Asian Finance, Economics and Business, 7(2), 249-260. https://doi. org/10.13106/jafeb.2020.vol7.no2.249 
Alpkan, L. ütfiha., Şanal, M., \& Ayden, Y. ükse. (2012). Market Orientation, Ambidexterity and Performance Outcomes. Procedia - Social and Behavioral Sciences, 41, 461-468. https://doi.org/10.1016/j.sbspro.2012.04.056

Amit, R., \& Schoemaker, P. J. H. (1993). Strategic assets and organizational rent. Strategic Management Journal, 14(1), 3346. https://doi.org/10.1002/smj.4250140105

Barney, J. (1991). Barney, J. (1991). Firm Resources and Sustained Competitive Advantage. Journal of Management, 17(1), 99120. http://doi.org/10.1177/014920639101700108

Chamidah, N., Guntoro, B., \& Sulastri, E. (2020). Marketing Communication and Synergy of Pentahelix Strategy on Satisfaction and Sustainable Tourism. Journal of Asian Finance, Economics and Business, 7(3), 177-190. https://doi. org/10.13106/jafeb.2020.vol7.no3.177

Chin, W. (1998). The partial least squares approach to structural equation modeling. Modern Methods for Business Research, 295(2), 295-336. https://doi.org/10.1016/j.aap.2008.12.010

Chuang, S.-H., \& Lin, H.-N. (2013). The roles of infrastructure capability and customer orientation in enhancing customerinformation quality in CRM systems: Empirical evidence from Taiwan. International Journal of Information Management, 33(2), 271-281. https://doi.org/10.1016/j. ijinfomgt.2012.12.003

Distanont, A., \& Khongmalai, O. (2018). Kasetsart Journal of Social Sciences The role of innovation in creating a competitive advantage. Kasetsart Journal of Social Sciences, 41(1),1-7. https://doi.org/10.1016/j.kjss.2018.07.009

Elrehail, H. (2018). The relationship among leadership, innovation and knowledge sharing: A guidance for analysis. Data in Brief, 19(August), 128-133. https://doi.org/10.1016/j. dib.2018.04.138

Fornell, C., \& Larcker, D. F. (1981). Structural equation models with unobservable variables and measurement error: Algebra and statistics. Journal of Marketing Research, 382-388. https:// doi.org/10.2307/3150980

Giannikas, V., McFarlane, D., \& Strachan, J. (2019). Towards the deployment of customer orientation: A case study in third-party logistics. Computers in Industry, 104(January), 75-87. https:// doi.org/10.1016/j.compind.2018.10.005

Hair, J. F., Henseler, J., Dijkstra, T. K., \& Sarstedt, M. (2014). Common beliefs and reality about partial least squares: comments on Rönkkö and Evermann. Organizational Research Methods, 17(2), 182-209, https://doi.org/10.1177/1094428114526928

Ho, K. L. P., Nguyen, C. N., Adhikari, R., Miles, M. P., \& Bonney, L. (2017). Exploring market orientation, innovation, and financial performance in agricultural value chains in emerging economies. Journal of Innovation \& Knowledge, 3(3), 154163. https://doi.org/10.1016/j.jik.2017.03.008

Hudson, M., Smart, A., \& Bourne, M. (2001). Theory and practice in SME performance measurement systems. International Journal of Operations \& Production Management, 21(8), 1096-1115. https://doi.org/10.1108/EUM0000000005587
Ibrahim, S., \& Heng, L. H. (2015). The Roles of Learning in Stimulating Knowledge Sharing at SMEs. Procedia - Social and Behavioral Sciences, 172(January), 230-237. https://doi. org/10.1016/j.sbspro.2015.01.359

Ioanid, A., Deselnicu, D. C., \& Militaru, G. (2018). The impact of social networks on SMEs' innovation potential. Procedia Manufacturing, 22, 936-941. https://doi.org/10.1016/j. promfg.2018.03.133

Iqbal, T., Huq, F., \& Bhutta, M. K. S. (2018). Agile manufacturing relationship building with TQM, JIT, and firm performance: An exploratory study in apparel export industry of Pakistan. International Journal of Production Economics, 203(September), 24-37. https://doi.org/10.1016/j. ijpe.2018.05.033

Kubíčková, L., Votoupalová, M., \& Toulová, M.(2014). Key Motives for Internationalization Process of Small and Medium-Sized Enterprises. Procedia Economics and Finance, 12(March), 319-328. https://doi.org/10.1016/S2212-5671(14)00351-7

Haerani, S., Sumardi, Hakim, W., Hartini, \& Putra, A. H. P. K. (2020). Structural Model of Developing Human Resources Performance: Empirical Study of Indonesia States Owned Enterprises. Journal of Asian Finance, Economics and Business, 7(3), 211-221. https://doi.org/10.13106/jafeb.2020. vol7.no3.211

Limaj, E., \& Bernroider, E. W. N. (2019). The roles of absorptive capacity and cultural balance for exploratory and exploitative innovation in SMEs. Journal of Business Research, 94(September 2016), 137-153. https://doi.org/10.1016/j. jbusres.2017.10.052

Lorenzo, J. R. F., Rubio, M. T. M., \& Garcés, S. A. (2018). The competitive advantage in business, capabilities and strategy. What general performance factors are found in the Spanish wine industry? Wine Economics and Policy, 7(2), 94-108. https://doi.org/10.1016/j.wep.2018.04.001

Makassar.antaranews.com. (2010). Industri Makanan Dominasi Pertumbuhan Produksi Sulsel - ANTARA News Makassar. Retrieved January 21, 2018, from https://makassar.antaranews. $\mathrm{com} /$ berita/17584/industri-makanan-dominasi-pertumbuhanproduksi-sulsel

Murali, S., Pugazhendhi, S., \& Muralidharan, C. (2016). Modelling and Investigating the relationship of after sales service quality with customer satisfaction, retention and loyalty - A case study of home appliances business. Journal of Retailing and Consumer Services, 30(May), 67-83. https://doi.org/https:// doi.org/10.1016/j.jretconser.2016.01.001

Nurhilalia, Rahman Kadir, A., Mahlia, M., Jusni, \& Aditya, H. P. K. P. (2019). Determinant of market orientation on SME performance: RBV and SCP perspective. Journal of Distribution Science, 17(9), 35-45. https://doi.org/10.15722/ jds.17.09.201909.35

Porter, M. E. (1981). The Contributions of Industrial Organization to Strategic Management. The Academy of Management Review, 6(4), 609-620. https://doi.org/10.2307/257639 
Purwantini, A. H., \& Anisa, F. (2018). Analysis of the Utilization of Social Commerce for SMEs: Antecedents and Consequences. Kompartemen: Jurnal Ilmiah Akuntansi, 16(1). 47-63. https:// doi.org/10.30595/kompartemen.v16i1.2413

Rajapathirana, R. P. J., \& Hui, Y. (2018). Relationship between innovation capability, innovation type, and firm performance. Journal of Innovation \& Knowledge, 3(1), 44-55. https://doi. org/10.1016/j.jik.2017.06.002

Ramlawati, Putra, A. H. P. K., Yasni, Basalamah, J., \& Mappatompo, A. (2019, July). Why Millenials Eat Out From Home? BT 1st International Conference on Life, Innovation, Change and Knowledge (ICLICK 2018). 23(July), 240-243. https://doi. org/10.2991/iclick-18.2019.49

Ramlawati, R., \& Putra, A. H. P. K. (2018). Total Quality Management as the Key of the Company to Gain the Competitiveness, Performance Achievement and Consumer Satisfaction. International Review of Management and Marketing, 8(5), 60-69.

Razak, N. A., Pangil, F., Zin, M. L. M., Yunus, N. A. M., \& Asnawi, N. H. (2016). Theories of Knowledge Sharing Behavior in
Business Strategy. Procedia Economics and Finance, 37(16), 545-553. https://doi.org/10.1016/S2212-5671(16)30163-0

Rega, S., Naha, N., Mansor, A., \& Ramayah, T. (2014). Why Organisational Culture Drives Knowledge Sharing ? Procedia - Social and Behavioral Sciences, 129(May), 119-126. https:// doi.org/10.1016/j.sbspro.2014.03.656

Ruiz-Ortega, M. J., Parra-Requena, G., García-Villaverde, P. M., \& Rodrigo-Alarcon, J. (2017). How does the closure of interorganizational relationships affect entrepreneurial orientation? BRQ Business Research Quarterly, 20(3), 178191. https://doi.org/10.1016/j.brq.2017.04.003

Shmelev, S. E., Sagiyeva, R. K., Kadyrkhanova, Z. M., Chzhan, Y. Y., \& Shmeleva, I. A. (2018). Comparative Sustainability Analysis of Two Asian Cities: A Multidimensional Assessment of Taipei and Almaty. Journal of Asian Finance, Economics and Business, 5(3), 143-155. http://doi.org/10.13106/jafeb.2018.vol5.no3.143

Yi, H.-T., Han, C.-N., \& Cha, Y.-B. (2018). The Effect of Entrepreneurship of SMEs on Corporate Capabilities, Dynamic Capability and Technical Performances in South Korea. Journal of Asian Finance, Economics and Business, 5(4), 135-147. http://doi.org/10.13106/jafeb.2018.vol5.no4.135

\section{Appendix 1: Conceptual Framework}

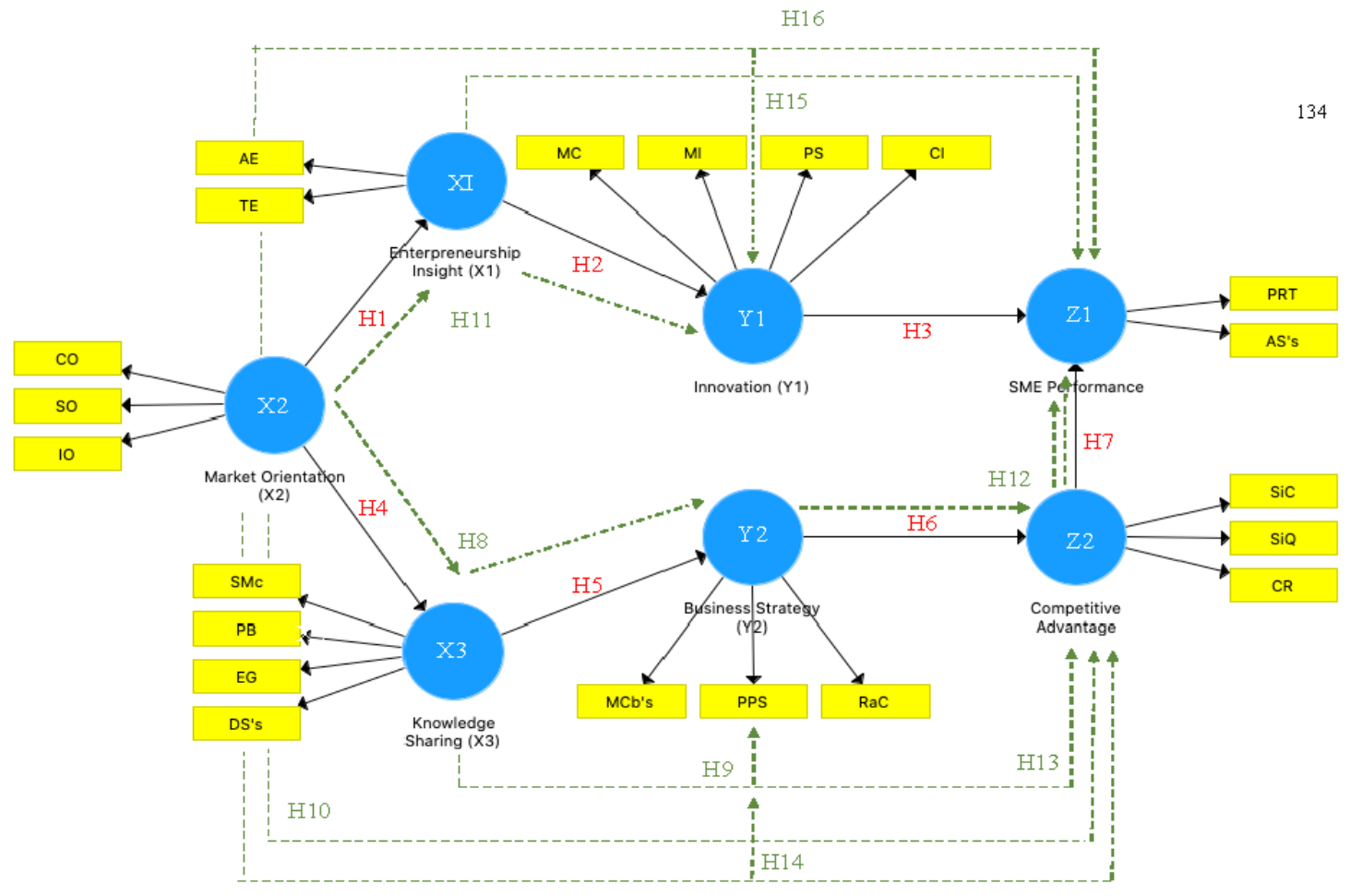


Appendix 2: Go-Food Partners Operating in Makassar City as of 2020

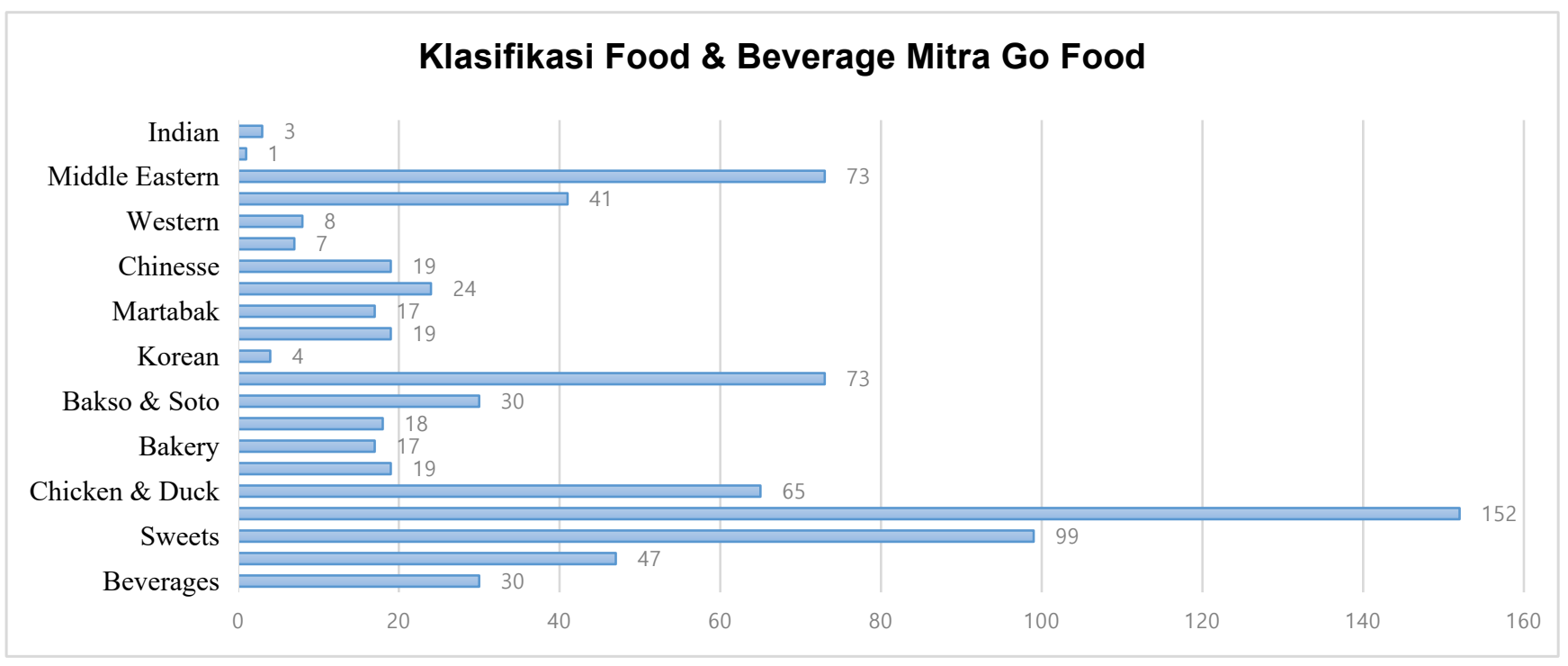

Source: Go-Jek application and reprocessed by researchers, 2020

Appendix 3: Characteristics of Respondents $(n=497)$

\begin{tabular}{|l|c|c|}
\hline \multicolumn{1}{|c|}{ Demographics } & Total & $\%$ \\
\hline Gender & & 43.3 \\
- Man & 215 & 56.7 \\
- Women & 282 & \\
\hline Age (Years) & & 15.2 \\
- $18-25$ & 76 & 15.8 \\
- $26-33$ & 78 & 53.2 \\
- $34-41$ & 264 & 14.6 \\
- $41-48$ & 73 & 1.2 \\
- Up to 48 & 6 & \\
\hline Marital status & & 60.1 \\
- Married & 299 & 39.9 \\
- Not Married & 198 & \\
\hline Education Level & & 43 \\
- High school & 213 & 7.6 \\
- Diploma & 38 & 21.5 \\
- Bachelor & 107 & 23.3 \\
- Masters & 116 & 4.7 \\
\hline
\end{tabular}


Appendix 4: Measurement of Variables

\begin{tabular}{|c|c|c|c|}
\hline Code & Variables & Item & Construct \\
\hline \multirow{2}{*}{ X1 } & \multirow{2}{*}{$\begin{array}{l}\text { Enterpreneurship } \\
\text { Insight }\end{array}$} & $\begin{array}{l}\text { Transactional } \\
\text { Entrepreneurship } \\
\text { (TW) }\end{array}$ & $\begin{array}{l}\text { - Ability to motivate internal business } \\
\text { - Ability to influence subordinates } \\
\text { - Intellectual ability } \\
\text { - The personality that reflects the authority as a leader }\end{array}$ \\
\hline & & $\begin{array}{l}\text { Authentic } \\
\text { Entrepreneurship } \\
(\mathrm{AE})\end{array}$ & $\begin{array}{l}\text { - Ability to give recognition to subordinates } \\
\text { - Be fair in making decisions } \\
\text { - Ability to build relationships } \\
\text { - Ability to improve business reputation }\end{array}$ \\
\hline \multirow{3}{*}{$\mathrm{X} 2$} & \multirow{3}{*}{$\begin{array}{l}\text { Market } \\
\text { Orientation }\end{array}$} & $\begin{array}{l}\text { Customer } \\
\text { Orientation (CO) }\end{array}$ & $\begin{array}{l}\text { - Meeting customer-based production needs } \\
\text { - Good relationships with customers } \\
\text { - Excellent service pre-selling and after selling }\end{array}$ \\
\hline & & $\begin{array}{l}\text { Supplier Orientation } \\
\text { (SO) }\end{array}$ & $\begin{array}{l}\text { - The ability to collaborate with suppliers } \\
\text { - Involve suppliers in developing new products } \\
\text { - Involving suppliers in the selection of raw materials or products }\end{array}$ \\
\hline & & $\begin{array}{l}\text { Industrial Orientation } \\
(\mathrm{IO})\end{array}$ & $\begin{array}{l}\text { - Industry involvement in providing guarantees of fair market } \\
\text { competition } \\
\text { - Industry involvement in meeting demand on schedule }\end{array}$ \\
\hline \multirow{4}{*}{ X3 } & \multirow{4}{*}{$\begin{array}{l}\text { Knowledge } \\
\text { Sharing }\end{array}$} & $\begin{array}{l}\text { SME Commitment } \\
\text { (SC) }\end{array}$ & $\begin{array}{l}\text { - Job satisfaction } \\
\text { - Business ability to develop internal organizational competencies } \\
\text { - The ability to be responsible internally within the organization } \\
\text { - Ability to give trust to subordinates }\end{array}$ \\
\hline & & $\begin{array}{l}\text { Business Perception } \\
\text { (PB) }\end{array}$ & $\begin{array}{l}\text { - Ability to apply technology in business activities } \\
\text { - The strength of leaders to provide benefits to the internal } \\
\text { organization } \\
\text { - The strength of the company to increase profits in a certain period }\end{array}$ \\
\hline & & $\begin{array}{l}\text { Employee } \\
\text { Engagement (EG) }\end{array}$ & $\begin{array}{l}\text { - Job satisfaction and feelings of life balance } \\
\text { - Future career prospects }\end{array}$ \\
\hline & & $\begin{array}{l}\text { Decision Making } \\
\text { System (DSS) }\end{array}$ & $\begin{array}{l}\text { - Mastery of computerized systems and technology access for SMEs } \\
\text { - Application of technology-based bookkeeping }\end{array}$ \\
\hline \multirow{4}{*}{ Y1 } & \multirow{4}{*}{ Innovation } & $\begin{array}{l}\text { Marketing Channels } \\
(\mathrm{MC})\end{array}$ & $\begin{array}{l}\text { - The ability of SMEs to use e-commerce sales access } \\
\text { - Repeat advertising } \\
\text { - The strength of SMEs to use social media access as a marketing } \\
\text { and promotional media } \\
\text { - The use of endorser figures to be more convincing of the products } \\
\text { being marketed }\end{array}$ \\
\hline & & $\begin{array}{l}\text { Marketing Innovation } \\
(\mathrm{MI})\end{array}$ & $\begin{array}{l}\text { - The ability of entrepreneurs and internal business in mastering the } \\
\text { products being marketed } \\
\text { - Conduct periodic evaluations of marketed products } \\
\text { - SMEs not only carry out marketing activities but also provide } \\
\text { education to customers }\end{array}$ \\
\hline & & $\begin{array}{l}\text { Product } \\
\text { Segmentation (PS) }\end{array}$ & $\begin{array}{l}\text { - Products that are marketed clearly in certain segments that include } \\
\text { age, gender and income level }\end{array}$ \\
\hline & & $\begin{array}{l}\text { Customer Insights } \\
(\mathrm{Cl})\end{array}$ & $\begin{array}{l}\text { - Oriented in development following the times } \\
\text { - Adapted to the protection and security of user data } \\
\text { - Modified on the selection of the best raw materials } \\
\text { - Be oriented to reasonable quality control before selling on the market } \\
\text { consumers }\end{array}$ \\
\hline
\end{tabular}




\begin{tabular}{|c|c|c|c|}
\hline Code & Variables & Item & Construct \\
\hline \multirow{3}{*}{ Y2 } & \multirow{3}{*}{$\begin{array}{l}\text { Business } \\
\text { Strategy }\end{array}$} & $\begin{array}{l}\text { Managerial } \\
\text { Capability (MC's) }\end{array}$ & $\begin{array}{l}\text { - Have a clear business mission vision } \\
\text { - The ability to establish excellent communication with customers } \\
\text { - Ability to achieve the specified target }\end{array}$ \\
\hline & & $\begin{array}{l}\text { Products, Processes } \\
\text { and Services (PPS) }\end{array}$ & $\begin{array}{l}\text { - Conformity between the products offered and the products provided } \\
\text { to consumers } \\
\text { - Utilization of technology to facilitate consumers in the process of } \\
\text { ordering and payment of goods purchased } \\
\text { - Excellent service, friendly and responsive to every customer } \\
\text { complaint }\end{array}$ \\
\hline & & $\begin{array}{l}\text { Resource Capability } \\
\text { (RC) }\end{array}$ & $\begin{array}{l}\text { - The ability of SME businesses that have capable employees in using } \\
\text { the latest technology to facilitate marketing access }\end{array}$ \\
\hline \multirow{2}{*}{ Z1 } & \multirow{2}{*}{$\begin{array}{l}\text { SME } \\
\text { Performance }\end{array}$} & Benefits (PRT) & $\begin{array}{l}\text { - SME performance improves if all work activities run effectively and } \\
\text { efficiently } \\
\text { - Improved SME performance, one of which can be seen from the } \\
\text { maximum profit increase } \\
\text { - SME performance improves if sales reach targets or exceed targets } \\
\text { - Improved SME performance can be regarded from the extent to } \\
\text { which the company's ability to pay obligations (liabilities) }\end{array}$ \\
\hline & & Assets (AAs) & $\begin{array}{l}\text { - The performance of SMEs improves if their physical assets have } \\
\text { increased in terms of quality and quantity } \\
\text { - SME performance improves if employees as an internal part of the } \\
\text { organization are disciplined in compliance with regulations } \\
\text { - An excellent SME performance can also be measured if the } \\
\text { employees feel comfortable, feel satisfied and feel comfortable } \\
\text { working in the company }\end{array}$ \\
\hline \multirow{3}{*}{$\mathrm{Z2}$} & \multirow{3}{*}{$\begin{array}{l}\text { Competitive } \\
\text { Advantage }\end{array}$} & $\begin{array}{l}\text { Superior } \\
\text { efficiency (SE) }\end{array}$ & $\begin{array}{l}\text { - The efficient use of a budget that is illustrated through the selection } \\
\text { of appropriate technology to cut variable costs } \\
\text { - The ability of SMEs in acquiring products to be marketed directly } \\
\text { from the source (industry) }\end{array}$ \\
\hline & & $\begin{array}{l}\text { Superior Quality } \\
\text { (SQ) }\end{array}$ & $\begin{array}{l}\text { The ability of SME businesses in presenting quality products at } \\
\text { competitive prices } \\
\text { - The strength of SME businesses to provide faster and responsible } \\
\text { delivery access } \\
\text { - Products marketed have excellent durability }\end{array}$ \\
\hline & & $\begin{array}{l}\text { Customer } \\
\text { Responsibility (CR) }\end{array}$ & $\begin{array}{l}\text { - The accuracy and speed of SMEs in providing services through easy } \\
\text { and up-to-date communication access } \\
\text { - SME's internal business expertise in providing detailed explanations } \\
\text { of products marketed to consumers } \\
\text { - Ease of consumers in finding, paying and tracking every transaction } \\
\text { that they have done } \\
\text { - Provision of more trusted e-commerce accounts for consumers in } \\
\text { terms of transactions }\end{array}$ \\
\hline
\end{tabular}


Appendix 5: Goodness of Fit Model

\begin{tabular}{|c|c|c|c|c|c|c|c|c|}
\hline Variables & Indicators & Item & $\begin{array}{l}\text { Deleted } \\
\text { Item }\end{array}$ & $\begin{array}{l}\text { Loading } \\
\text { Factor }\end{array}$ & $\begin{array}{c}\text { Cronbach } \\
\text { Alpha }\end{array}$ & rho_A & $\begin{array}{l}\text { Composite } \\
\text { reliability }\end{array}$ & AVE \\
\hline \multirow[t]{2}{*}{$\begin{array}{l}\text { Entrepreneurship } \\
\text { Insight (X1) }\end{array}$} & $\begin{array}{l}\text { Transactional Entrepreneurship } \\
\text { (TW) }\end{array}$ & $\begin{array}{l}\text { El1 } \\
\text { El3 } \\
\text { El4 } \\
\end{array}$ & \multirow[t]{2}{*}{ El2 } & $\begin{array}{l}0.720 \\
0.776 \\
0.739\end{array}$ & \multirow[t]{2}{*}{0.887} & \multirow[t]{2}{*}{0.890} & \multirow[t]{2}{*}{0.912} & \multirow[t]{2}{*}{0.599} \\
\hline & $\begin{array}{l}\text { Authentic Entrepreneurship } \\
(\mathrm{AE})\end{array}$ & $\begin{array}{l}\text { El5 } \\
\text { El6 } \\
\text { El7 } \\
\text { El8 }\end{array}$ & & $\begin{array}{l}0.732 \\
0.755 \\
0.873 \\
0.810\end{array}$ & & & & \\
\hline \multirow[t]{3}{*}{$\begin{array}{l}\text { Market } \\
\text { Orientation (X2) } \\
\end{array}$} & Customer Orientation (CO) & $\begin{array}{l}\text { MO1 } \\
\text { MO2 }\end{array}$ & \multirow[t]{3}{*}{$\begin{array}{l}\text { MO3 } \\
\text { MO9 }\end{array}$} & $\begin{array}{l}0.834 \\
0.874\end{array}$ & \multirow[t]{3}{*}{0.917} & \multirow[t]{3}{*}{0.919} & \multirow[t]{3}{*}{0.934} & \multirow[t]{3}{*}{0.668} \\
\hline & Supplier Orientation (SO) & $\begin{array}{l}\text { MO4 } \\
\text { MO5 } \\
\text { MO6 } \\
\text { MO7 }\end{array}$ & & $\begin{array}{l}0.777 \\
0.856 \\
0.775 \\
0.821\end{array}$ & & & & \\
\hline & Industrial Orientation (IO) & MO8 & & 0.778 & & & & \\
\hline \multirow[t]{4}{*}{$\begin{array}{l}\text { Knowledge } \\
\text { Sharing (X3) }\end{array}$} & SME Commitment (SC) & $\begin{array}{l}\text { KS1 } \\
\text { KS2 } \\
\text { KS3 } \\
\text { KS4 }\end{array}$ & \multirow[t]{4}{*}{$\begin{array}{l}\text { KS5 } \\
\text { KS6 } \\
\text { KS7 } \\
\text { KS8 }\end{array}$} & $\begin{array}{l}0.864 \\
0.795 \\
0.865 \\
0.874\end{array}$ & \multirow[t]{4}{*}{0.947} & \multirow[t]{4}{*}{0.948} & \multirow[t]{4}{*}{0.955} & \multirow[t]{4}{*}{0.729} \\
\hline & Business Perception (PB) & - & & - & & & & \\
\hline & Employee Engagement (EG) & $\begin{array}{l}\text { KS9 } \\
\text { KS10 }\end{array}$ & & $\begin{array}{l}0.864 \\
0.828\end{array}$ & & & & \\
\hline & $\begin{array}{c}\text { Decision Making System } \\
\text { (DSS) }\end{array}$ & $\begin{array}{l}\text { KS11 } \\
\text { KS12 }\end{array}$ & & $\begin{array}{l}0.890 \\
0.846\end{array}$ & & & & \\
\hline \multirow[t]{4}{*}{ Innovation (Y1) } & Marketing Channels (MC) & $\begin{array}{l}\text { IN3 } \\
\text { IN4 }\end{array}$ & \multirow{4}{*}{$\begin{array}{c}\text { IN1 } \\
\text { IN2 } \\
\text { IN14 }\end{array}$} & $\begin{array}{l}0.835 \\
0.758\end{array}$ & \multirow[t]{4}{*}{0.954} & \multirow[t]{4}{*}{0.955} & \multirow[t]{4}{*}{0.960} & \multirow[t]{4}{*}{0.686} \\
\hline & Marketing Innovation (MI) & $\begin{array}{l}\text { IN5 } \\
\text { IN6 } \\
\text { IN7 }\end{array}$ & & $\begin{array}{l}0.863 \\
0.784 \\
0.785\end{array}$ & & & & \\
\hline & Product Segmentation (PS) & IN8 & & 0.826 & & & & \\
\hline & Customer Insights $(\mathrm{Cl})$ & $\begin{array}{c}\text { IN9 } \\
\text { IN10 } \\
\text { IN11 } \\
\text { IN12 } \\
\text { IN13 }\end{array}$ & & $\begin{array}{l}0.833 \\
0.801 \\
0.894 \\
0.874 \\
0.849\end{array}$ & & & & \\
\hline \multirow[t]{3}{*}{$\begin{array}{l}\text { Business } \\
\text { Strategy (Y2) }\end{array}$} & Managerial Capability (MC's) & $\begin{array}{l}\text { BS1 } \\
\text { BS2 } \\
\text { BS3 }\end{array}$ & \multirow[t]{3}{*}{-} & $\begin{array}{l}0.872 \\
0.904 \\
0.924\end{array}$ & \multirow[t]{3}{*}{0.945} & \multirow[t]{3}{*}{0.946} & \multirow[t]{3}{*}{0.955} & \multirow[t]{3}{*}{0.752} \\
\hline & $\begin{array}{l}\text { Products, Processes and } \\
\text { Services (PPS) }\end{array}$ & $\begin{array}{l}\text { BS4 } \\
\text { BS5 } \\
\text { BS6 }\end{array}$ & & $\begin{array}{l}0.865 \\
0.854 \\
0.829\end{array}$ & & & & \\
\hline & $\begin{array}{l}\text { Resource Capability } \\
\text { (RC) }\end{array}$ & BS7 & & 0.817 & & & & \\
\hline
\end{tabular}




\begin{tabular}{|c|c|c|c|c|c|c|c|c|c|c|c|}
\hline Variables & \multicolumn{2}{|c|}{ Indicators } & Item & $\begin{array}{l}\text { Deleted } \\
\text { Item }\end{array}$ & $\begin{array}{l}\text { Loading } \\
\text { Factor }\end{array}$ & $\begin{array}{r}\text { Cro } \\
\text { Al }\end{array}$ & ach & rho_A & $\begin{array}{r}\text { Comp } \\
\text { reliab }\end{array}$ & $\begin{array}{l}\text { site } \\
\text { lity }\end{array}$ & AVE \\
\hline $\begin{array}{l}\text { SME } \\
\text { Performance } \\
(\mathrm{Z1})\end{array}$ & \multicolumn{2}{|c|}{ Benefits (PRT) } & $\begin{array}{l}\text { SMP1 } \\
\text { SMP2 } \\
\text { SMP4 }\end{array}$ & \multirow[t]{2}{*}{ SMP3 } & $\begin{array}{l}0.934 \\
0.913 \\
0.804\end{array}$ & \multirow{2}{*}{\multicolumn{2}{|c|}{0.924}} & \multirow[t]{2}{*}{0.928} & \multirow{2}{*}{\multicolumn{2}{|c|}{0.941}} & \multirow[t]{2}{*}{0.729} \\
\hline & \multicolumn{2}{|c|}{ Assets (AAs) } & $\begin{array}{l}\text { SMP5 } \\
\text { SMP6 } \\
\text { SMP7 }\end{array}$ & & $\begin{array}{l}0.858 \\
0.851 \\
0.750\end{array}$ & & & & & & \\
\hline $\begin{array}{l}\text { Competitive } \\
\text { Advantage (Z2) }\end{array}$ & \multicolumn{2}{|c|}{ Superior efficiency (SE) } & $\begin{array}{l}\text { CA1 } \\
\text { CA2 }\end{array}$ & \multirow[t]{3}{*}{-} & $\begin{array}{l}0.897 \\
0.882\end{array}$ & \multirow{3}{*}{\multicolumn{2}{|c|}{0.941}} & \multirow[t]{3}{*}{0.943} & \multirow{3}{*}{\multicolumn{2}{|c|}{0.951}} & 0.684 \\
\hline & \multicolumn{2}{|c|}{ Superior Quality (SQ) } & $\begin{array}{l}\text { CA3 } \\
\text { CA4 } \\
\text { CA5 }\end{array}$ & & $\begin{array}{l}0.724 \\
0.709 \\
0.831\end{array}$ & & & & & & \\
\hline & \multicolumn{2}{|c|}{ Customer Responsibility (CR) } & $\begin{array}{l}\text { CA6 } \\
\text { CA7 } \\
\text { CA8 } \\
\text { CA9 }\end{array}$ & & $\begin{array}{l}0.825 \\
0.884 \\
0.856 \\
0.813\end{array}$ & & & & & & \\
\hline \multicolumn{3}{|c|}{ Variables } & \multicolumn{2}{|c|}{$R$ square } & \multicolumn{7}{|c|}{$R$ square Adjusted } \\
\hline \multicolumn{3}{|c|}{ Entrepreneurship Insight (X1) } & \multicolumn{2}{|c|}{0.783} & \multicolumn{7}{|c|}{0.781} \\
\hline \multicolumn{3}{|c|}{ Knowledge Sharing (X3) } & \multicolumn{2}{|c|}{0.809} & \multicolumn{7}{|c|}{0.807} \\
\hline \multicolumn{3}{|l|}{ Innovation (Y1) } & \multicolumn{2}{|c|}{0.904} & \multicolumn{7}{|c|}{0.903} \\
\hline \multicolumn{3}{|c|}{ Business Strategy (Y2) } & \multicolumn{2}{|c|}{0.895} & \multicolumn{7}{|c|}{0.894} \\
\hline \multicolumn{3}{|c|}{ SME Performance $(Z 1)$} & \multicolumn{2}{|c|}{0.908} & \multicolumn{7}{|c|}{0.906} \\
\hline Competitive Advant & tage $(Z 2)$ & & & 26 & & & & 0.925 & & & \\
\hline & $\begin{array}{l}\text { Entrepreneur- } \\
\text { ship Insight }\end{array}$ & $\begin{array}{c}\text { Market } \\
\text { Orientation }\end{array}$ & $\begin{array}{r}\text { Knol } \\
\text { Sh }\end{array}$ & $\begin{array}{l}\text { ledge } \\
\text { ring }\end{array}$ & Innovat & ion & $\begin{array}{l}\text { Bus } \\
\text { Str }\end{array}$ & $\begin{array}{l}\text { iness } \\
\text { ategy }\end{array}$ & $\begin{array}{c}\text { SME } \\
\text { Perfor- } \\
\text { mance }\end{array}$ & $\begin{array}{l}\text { Com } \\
\text { Adv }\end{array}$ & $\begin{array}{l}\text { etitive } \\
\text { antage }\end{array}$ \\
\hline $\begin{array}{l}\text { Entrepreneurship } \\
\text { Insight }\end{array}$ & & & & & 9.460 & & & & & & \\
\hline $\begin{array}{l}\text { Market } \\
\text { Orientation }\end{array}$ & 3.609 & & & 25 & & & & & & & \\
\hline $\begin{array}{l}\text { Knowledge } \\
\text { Sharing }\end{array}$ & & & & & & & & 518 & & & \\
\hline Innovation & & & & & & & & & 0.197 & & \\
\hline Business Strategy & & & & & & & & & & & 560 \\
\hline SME Performance & & & & & & & & & & & \\
\hline $\begin{array}{l}\text { Competitive } \\
\text { Advantage }\end{array}$ & & & & & & & & & 0.154 & & \\
\hline
\end{tabular}


Appendix 6: Hypotheses Test

\begin{tabular}{|c|c|c|c|c|c|c|}
\hline Path & Hypotheses & Mean & $\begin{array}{l}\text { Standard } \\
\text { Deviation }\end{array}$ & T-Stat & P-Value & Info \\
\hline $\mathrm{H} 1$ & & 0.887 & 0.021 & 41.444 & $<0.01$ & Support \\
\hline $\mathrm{H} 2$ & Entrepreneurship Insight $\rightarrow$ Innovation & 0.952 & 0.009 & 101.366 & $<0.01$ & Support \\
\hline $\mathrm{H} 3$ & Innovation $\rightarrow$ SME Performance & 0.487 & 0.127 & 4.013 & $<0.01$ & Support \\
\hline $\mathrm{H} 4$ & Market orientation $\rightarrow$ Knowledge sharing & 0.901 & 0.018 & 50.152 & $<0.01$ & Support \\
\hline $\mathrm{H} 5$ & Knowledge sharing $\rightarrow$ Business Strategy & 0.947 & 0.011 & 89.090 & $<0.01$ & Support \\
\hline $\mathrm{H} 6$ & $\begin{array}{l}\text { Business Strategy } \rightarrow \text { Competitive } \\
\text { advantage }\end{array}$ & 0.963 & 0.008 & 123.850 & $<0.01$ & Support \\
\hline $\mathrm{H} 7$ & $\begin{array}{l}\text { Competitive advantage } \rightarrow \text { SME } \\
\text { Performance }\end{array}$ & 0.475 & 0.128 & 3.523 & $<0.01$ & Support \\
\hline $\mathrm{H} 8$ & $\begin{array}{l}\text { Market orientation } \rightarrow \text { Knowledge sharing } \\
\rightarrow \text { Business Strategy }\end{array}$ & 0.853 & 0.025 & 34.564 & $<0.01$ & Support \\
\hline $\mathrm{H} 9$ & $\begin{array}{l}\text { Knowledge sharing } \rightarrow \text { Business Strategy } \\
\rightarrow \text { Competitive Advantage }\end{array}$ & 0.912 & 0.016 & 58.218 & $<0.01$ & Support \\
\hline $\mathrm{H} 10$ & $\begin{array}{l}\text { Market orientation } \rightarrow \text { Knowledge Sharing } \\
\rightarrow \text { Business strategy } \rightarrow \text { Competitive } \\
\text { advantage }\end{array}$ & 0.821 & 0.028 & 29.487 & $<0.01$ & Support \\
\hline $\mathrm{H} 11$ & $\begin{array}{l}\text { Market orientation } \rightarrow \text { Entrepreneurship } \\
\text { insight } \rightarrow \text { Innovation }\end{array}$ & 0.844 & 0.026 & 32.899 & $<0.01$ & Support \\
\hline $\mathrm{H} 12$ & $\begin{array}{l}\text { Business strategy } \rightarrow \text { Competitive } \\
\text { advantage } \rightarrow \text { SME } \\
\text { performance }\end{array}$ & 0.458 & 0.123 & 3.520 & $<0.01$ & Support \\
\hline $\mathrm{H} 13$ & $\begin{array}{l}\text { Knowledge sharing } \rightarrow \text { Business strategy } \\
\rightarrow \text { Competitive } \\
\text { advantage } \rightarrow \text { SME performance }\end{array}$ & 0.433 & 0.117 & 3.512 & $<0.01$ & Support \\
\hline $\mathrm{H} 14$ & $\begin{array}{l}\text { Market orientation } \rightarrow \text { Knowledge sharing } \\
\rightarrow \text { Business strategy } \rightarrow \text { Competitive } \\
\text { advantage }\end{array}$ & 0.391 & 0.106 & 3.475 & $<0.01$ & Support \\
\hline $\mathrm{H} 15$ & $\begin{array}{l}\text { Entrepreneurship insight } \rightarrow \text { Innovation } \rightarrow \\
\text { SME Performance }\end{array}$ & 0.463 & 0.122 & 3.975 & $<0.01$ & Support \\
\hline $\mathrm{H} 16$ & $\begin{array}{l}\text { Market orientation } \rightarrow \text { Entrepreneurship } \\
\text { insight } \rightarrow \text { Innovation } \rightarrow \text { SME Performance }\end{array}$ & 0.411 & 0.108 & 3.965 & $<0.01$ & Support \\
\hline
\end{tabular}

